\title{
Role of LDL level over hospital stay length of surgically treated coronary artery and obstructive peripheral arterial disease patients
}

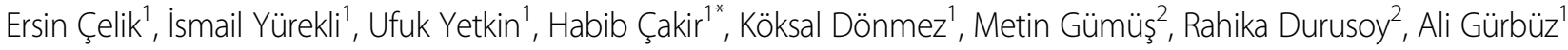 \\ From World Society of Cardiothoracic Surgeons 25th Anniversary Congress, Edinburgh \\ Edinburgh, UK. 19-22 September 2015
}

\section{Background/Introduction}

Atherosclerosis is the most common and most important risk factor for cardiovascular diseases.

\section{Aims/Objectives}

Between dates January 2007 and December 2010, 868 coronary artery disease, and 268 peripheral vascular disease patients who were treated surgically at our clinic were investigated.

\section{Method}

Mean age of 868 coronary artery disease patients were $63,86 \pm 11,17$ (between 21-91 years) and 268 peripheral arterial disease patients were $65,44 \pm 10,37$ (between 2192 years).

\section{Results}

Between 868 patients underwent surgery for coronary artery disease, LDL cholesterol level of 518 patients were $>100 \mathrm{mg} / \mathrm{dl}$ and 350 patients were $<100 \mathrm{mg}<7 \mathrm{mg} / \mathrm{dl}$. Mean hospital stay length of patients was 6,8 days and 6,19 days, respectively. This difference was significant $(p<0.05)$.Between 268 patients underwent surgery for peripheral arterial disease, LDL cholesterol level of 177 patients were $>100 \mathrm{mg} / \mathrm{dl}$ and 91 patients were $<100$ $\mathrm{mg}<7 \mathrm{mg} / \mathrm{dl}$. There was any significant correlation between LDL cholesterol levels and intensive care or hospital stay length $(\mathrm{p}>0.05)$.

\section{Discussion/Conclusion}

We believe that, precise examination of preoperative risk factors and providing adequate pre and per operative

Department of Cardiovascular Surgery, Katip Celebi University Izmir Ataturk Training and Research Hospital, Izmir, Turkey

Full list of author information is available at the end of the article medication will significantly reduce surgical morbidity rates, intensive care unit, and hospital stay lengths of coronary and peripheral arterial disease patients.

\section{Consent}

Written informed consent was obtained from the patient for publication of this Case report and any accompanying images. A copy of the written consent is available for review by the Editor-in-Chief of this journal.

\section{Authors' details}

'Department of Cardiovascular Surgery, Katip Celebi University Izmir Ataturk Training and Research Hospital, Izmir, Turkey. ${ }^{2}$ Department of Public Health, Medical Sciences Faculty, Ege University, Bornova, 35040 Bornova/Izmir, Turkey.

\section{Published: 16 December 2015}

\section{doi:10.1186/1749-8090-10-S1-A228}

Cite this article as: Çelik et al.: Role of LDL level over hospital stay length of surgically treated coronary artery and obstructive peripheral arterial disease patients. Journal of Cardiothoracic Surgery 2015 10(Suppl 1):A228

Submit your next manuscript to BioMed Central and take full advantage of:

- Convenient online submission

- Thorough peer review

- No space constraints or color figure charges

- Immediate publication on acceptance

- Inclusion in PubMed, CAS, Scopus and Google Scholar

- Research which is freely available for redistribution 